\title{
Agro-ecological Differentials in Soybean Crop Evapotranspiration and Implications for Adaptation to Climate Change
}

\author{
Ernest L. MOLUA \\ Department of Economics and Management, University of Buea, Cameroon. Tel: +237 99.49.43.93; Email: \\ emolua@gmx.net
}

\begin{abstract}
This study estimated soybean crop evapotranspiration from weather data using the cropwat model. The effects of reference evapotranspiration, crop coefficients, and yield response factor were quantified for three different agroecological zones in Cameroon. The evapotranspiration of soybean was observed to be $281.03 \mathrm{~mm}$ in the farming district of Ambam, $387.7 \mathrm{~mm}$ in Bamenda and $605.3 \mathrm{~mm}$ in Garoua, indicating pronounced differences in the agro-ecologies. Across the three regions studied, rainfall pattern determines soil water reserves and crop water uptake. In the farming zones of Bamenda and Ambam, water requirement for soybean are met by the rainfall. In the northern region of the country, irrigation needs are high. As a consequence, actual crop evapotranspiration is greatest in the hot dry zone of Garoua and lowest in the cool humid region of Bamenda. From this study it could be concluded that coping with climatic variations and future climate change will require complementary irrigation as well as improved crop management practices.
\end{abstract}

Keywords: soybean, climate variation, crop water requirements, Cameroon

\section{Introduction}

In Cameroon a variety of arable crops are grown, including soybean (Glycine max, Leguminosae) a dicotyledonous annual oil crop that is photoperiod sensitive, whose economic importance for household and industrial use is increasing. Climate variability is an important source of risk in soybean production since it affects yield variation and often leads to yield losses. Increased frequency of climate is expected to be associated with future climate change [1]. Climate change will therefore enhance farm risks by influencing crop growth and development, resulting in yield reduction [2]. The stability of soybean production systems in the country will therefore have to depend on adaptation strategies and mitigation measures in relation to water control. Crop water control is primarily a question of management that depends on strategic choices which must be considered well before the farming season. This may involve issues that border on choice of cropping plan according to farm constraints, e.g. which crops to irrigate and income margin objectives, and provisional irrigation programme. These strategic choices are determinant for the tactical decisions made during the cropping season.
Cameroon, characterized by two climatic types in terms of the relative duration and intensity of the wet and dry periods in different parts of the country, is an interesting location for such a study. The climate has a pronounced wet period from May to November, and a dry period from December to April. Climate variability conditions affect the spatial and temporal distribution of rainfall in tropical soybean-growing areas. More importantly, the interactions of precipitation occurrence can impact the health of crops and land productivity, as unstable climate affects important parameters on crop reproductive and vegetative growth. This may include water stress during critical growth periods which could reduce yield and quality of crops. These are important because crop water use is weather dependent as well as soil, water and plant dependent $[3,4]$. Farm proprietors now periodically check soil water at different depths within the root zone and at different growth stages to avoid stressing the crop during critical growth stages.

Of all the climatic variables, precipitation is a leading factor affecting land value through crop yields $[5,6,7]$. Some other studies reveal that water deficit treatments reduced the overall biomass of soybeans [8]. Equally, temperature changes affect crop productivity $[9,10]$; by influencing respiration and transpiration rates 
$[11,12,13]$. For instance, flowering may be partially triggered by higher temperatures, while low temperatures may reduce energy use and increased sugar storage. Yields have been shown to increase in proportion to other variable changes such as solar radiation and temperature with increased amounts of $\mathrm{CO}_{2}$ [14]. Generally, significant changes in yield result when the precipitation factor was altered.

Several studies using temperature gradient tunnels, crop simulation models, and field experiments have been conducted to evaluate the effects of climate change on soybeans crop growth and development, particularly temperature increase and increased or double $\mathrm{CO}_{2}$ concentration $[15,16,17]$. In general, simulation analyses and field experiments have shown a reduction in soybeans yields. The same studies have also shown that soybeans varieties respond nonlinearly with increased $\mathrm{CO}_{2}$ concentration [18, $19,20]$. This paper thus analyses the effects of climate variation on soybean crop evapotranspiration in different ecological zones in Cameroon, in order to highlight the implications for adapting to potential climate change.

\section{Methods}

This study employs the methodologies from the FAO Land and Water Development Division on crop water management at the farm level to calculate crop water requirements and crop water productivity in irrigated and rainfed agriculture [21, $22,23,24]$. Crop water requirement allows us to simulate the effect of climate and soil crop performance. Using monthly averages of the climatic parameters (minimum and maximum air temperature, rainfall, relative humidity, sunshine duration, wind speed and geographic coordinates i.e. altitude, latitude, longitude) obtained from CLIMWAT [26], the Cropwat software was employed to calculate reference evapotranspiration (Eto), effective rainfall, maximum evapotranspiration, crop water requirements (CWR) and irrigation needs. The tool uses the Penman-Monteith method for calculating the reference crop evapotranspiration $[6,24,25]$. The cropping patterns consisted of the planting date, crop coefficient data (including $\mathrm{Kc}$ values, stage days, root depth, depletion fraction) and the area planted (0-100\% of the total area). The crop coefficient data are provided in the software. Effective rain is estimated to be $80 \%$ of rainfall amount. Irrigation is applied when $80 \%$ of easily useable reserve is exhausted and has $70 \%$ efficiency. The maximum crop root zone depths (z) is $100 \mathrm{~cm}$.

For comparative analysis, as shown in table 1, we select the farming district of Ambam in the humid moist forest zone, the farming community in Bamenda in the high savanna zone and farms in the sahel savanna zone in Garoua. These study areas offer diverse information on temperature, rainfall, sunshine and wind speed that allows for the examination of their influence on the cropping patterns and specific crop requirements.

As shown in figure 1 , temperature in all regions are very high with an average of $28^{\circ} \mathrm{C}$, with the month of April having $40-42^{\circ} \mathrm{C}$ maximum, $40^{\circ} \mathrm{C}$ in average, and January having the minimum average of $26^{\circ} \mathrm{C}$. Average annual temperature is close to $25^{\circ} \mathrm{C}$ with small ranges of $1-3^{\circ} \mathrm{C}$. The $12-$ month average rainfall totals about $500 \mathrm{~mm}$ with constant humidity of more than $80 \%$ especially during the period of precipitation that brings along cloudiness and constant humidity of over $85 \%$. In Garoua, for instance, average annual rainfall ranges between 900-1000 mm. December, January and February experience no rainfall (0 $\mathrm{mm}$ ) while August is highest with $209 \mathrm{~mm}$ of rainfall as revealed in figure 2 . Sunshine (see figure 3 ) is associated with the low humidity, slightly above $10 \%$.

Table 1: Geographic description of study zones

\begin{tabular}{lccccc}
\hline \multirow{2}{*}{$\begin{array}{l}\text { Farming } \\
\text { district }\end{array}$} & \multicolumn{3}{c}{ Location } & & \\
\cline { 2 - 4 } & Long. & Lat. & Alt. & Ecology & Soil Type \\
\hline Ambam & $11.27{ }^{\circ} \mathrm{E}$, & $2.34 \mathrm{o}^{\mathrm{N}}$ & $602 \mathrm{~m}$ & Humid Moist Forest & Vertisols \\
Bamenda & $10.15^{\circ} \mathrm{E}$ & $5.970^{\circ} \mathrm{N}$ & $1609 \mathrm{~m}$ & High Savanna & Ferralsols \\
Garoua & $13.38^{\circ} \mathrm{E}$ & $9.33^{\circ} \mathrm{N}$ & $244 \mathrm{~m}$ & Sahel Savanna & $\begin{array}{c}\text { Ferruginous, hydromorphic- } \\
\text { fluvisols }\end{array}$ \\
\hline
\end{tabular}



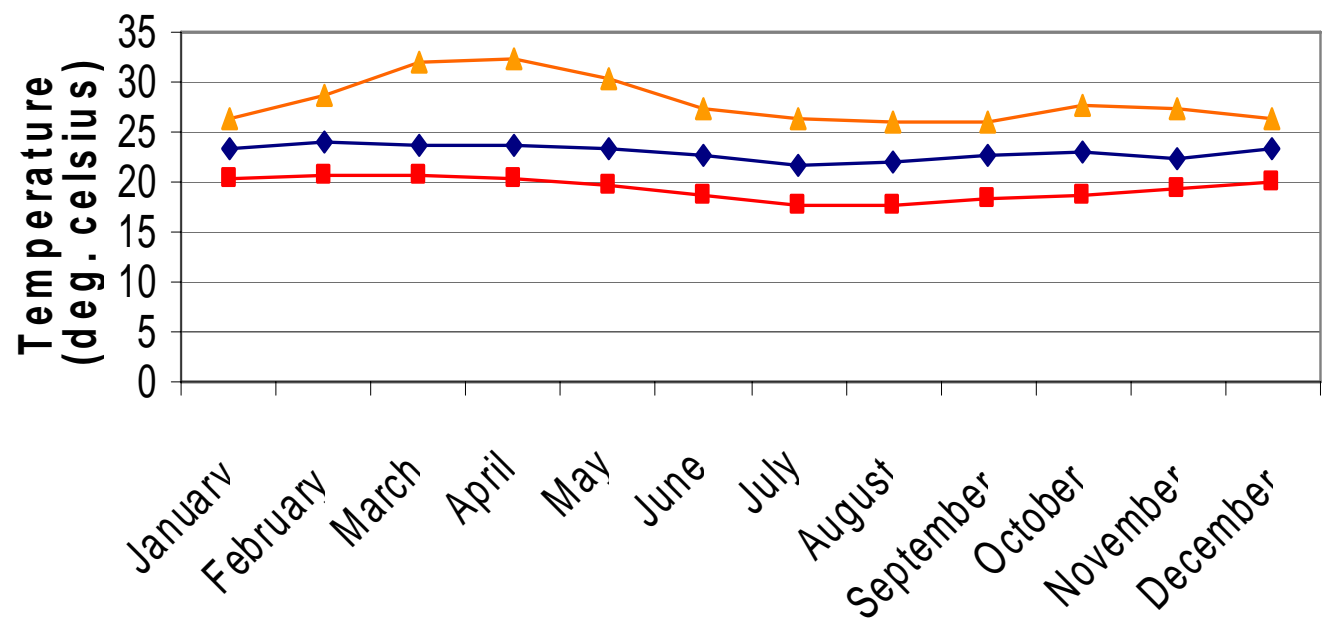

$\rightarrow$ Ambam $\rightarrow-$ Bamenda $\rightarrow-$ Garoua

Figure 1: Mean Monthly Temperature Distribution in the Study Zones
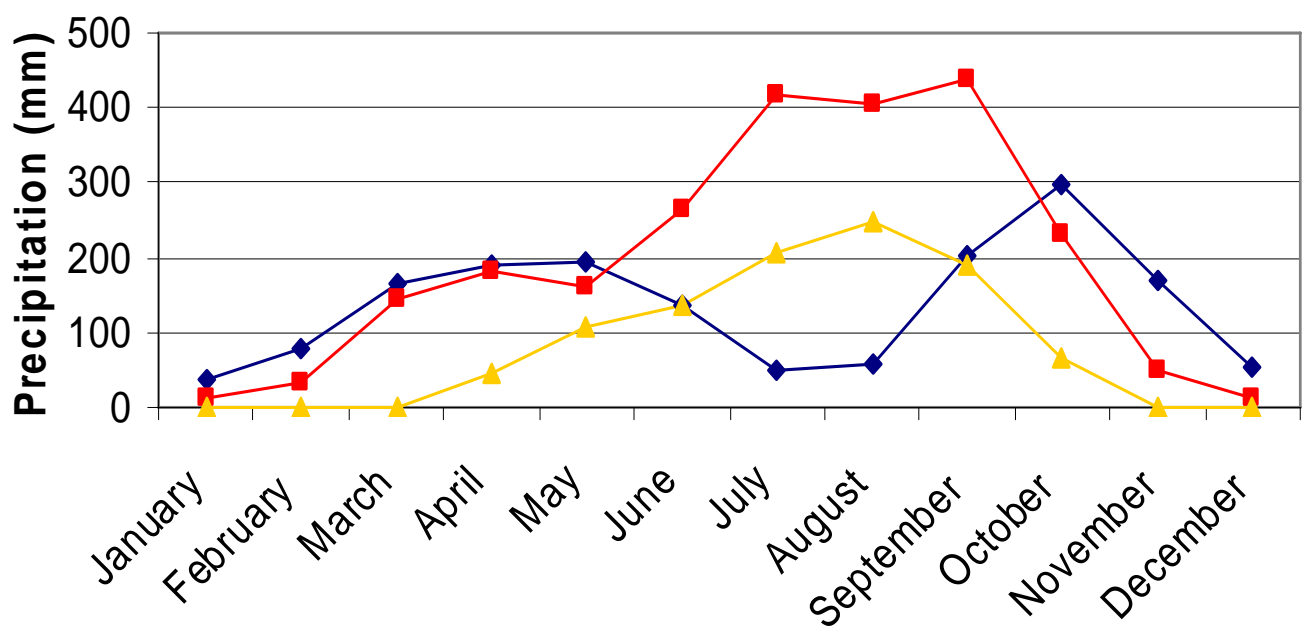

\section{$\multimap$ Ambam $\rightarrow$ Bamenda $\multimap$ Garoua}

Figure 2: Mean Monthly Precipitation Distribution in the Study Zones 


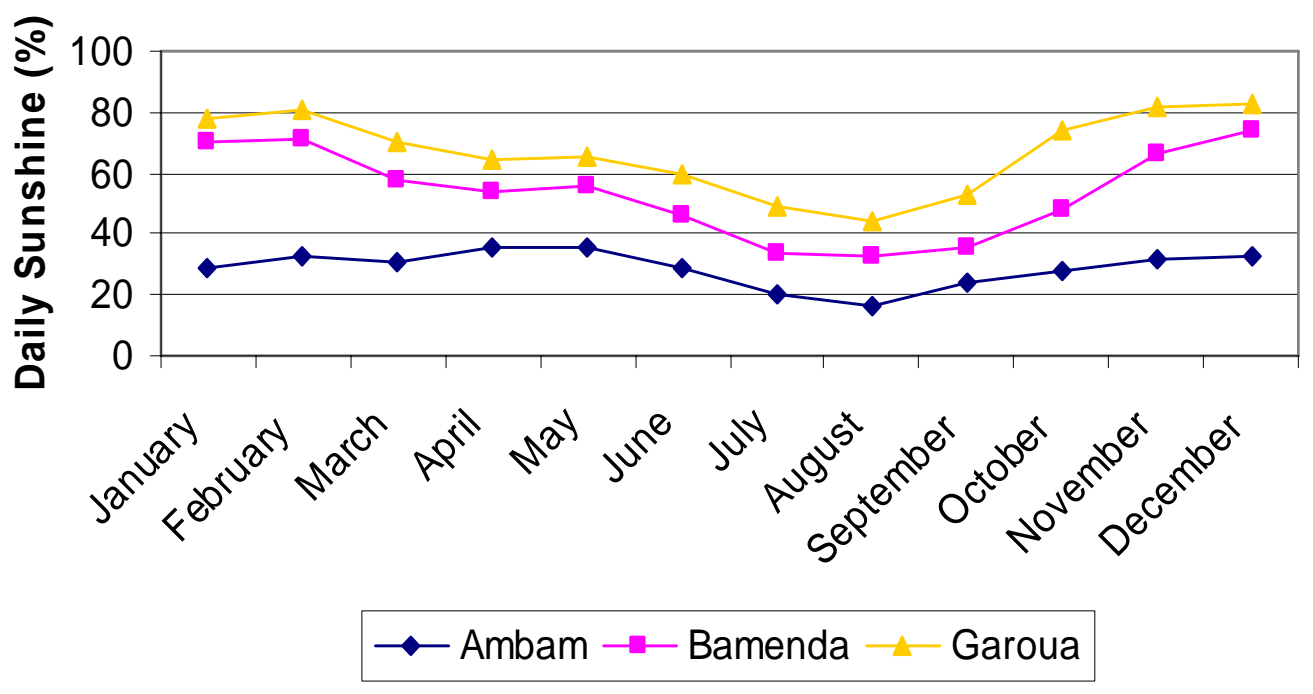

Figure 3: Comparative Distribution of Sunshine in the Study Areas

\section{Empirical Results}

\subsection{Farming and Cropping Practices}

While soybean will grow on nearly all types of soil, they are more productive on fertile loams. In the farming districts studied, soybeans are grown year-round in well drained soils that are neither too acid nor too alkaline. In the absence of modern inputs of Lime and fertiliser, most farmers apply composts or manure to improve the soil condition and fertility. For maximum yield, Soybeans are planted directly into seedbeds at a depth of 2.45 to $3.81 \mathrm{~cm}$, with spacing between rows of $45 \mathrm{~cm}$; and 8-10 cm between plants within the rows. Some producers use narrower rows 25.4 or $50.8 \mathrm{~cm}$. The seeding rate is approximately 8-12, 6-8, and 4-6 plants (per $30 \mathrm{~cm}$ ) in 75,50 , and $25 \mathrm{~cm}$ rows respectively. Early weed control is needed as the early growth of soybean is relative slow.

An important requirement for vegetative and reproductive growth is regular irrigation so that there is ample moisture supply for the plants at all times. However, insect and disease attack constrain vegetative growth. The insects that most commonly attack soybeans are beanflies, beetles, red spider mite and stink bugs. These could be controlled by a regular insecticide spray program starting from the time of seedling emergence. However, optimal agricultural production is constrained by farmers' inability to timely secure much needed inputs: pesticides, fertiliser and improved seeds. Problems thus arise when conditions are favourable for disease organisms, such as the Rhizoctonia root rot that affects young plants during wet weather or when the soil becomes waterlogged. Foliage diseases are a problem during wet weather. Under favourable climatic conditions, vegetable soybeans are ready for harvest about $65-70$ days after planting. The most efficient harvesting is when the moisture content drops to 12 percent. Late harvesting increases pod shattering. Most losses are caused by shattering in the field during cutting, threshing and separating. Because of the higher oil content, beans must be stored at lower moisture content (10 to 12 percent) than cereals.

\subsection{Crop Selection and Agronomic Development}

The soybean is a versatile crop that can be used for many purposes. Planting on time is necessary to obtain enough plant growth and development for good yields. If planting is delayed beyond the optimum date, yields are reduced. Likewise, planting too early can reduce yields. Like other crops, soybeans are more likely to reach their yield potential on soils with no rooting restrictions, high fertility and adequate moisture. As shown in table 2 the intervals between the development phases are not equally sensitive to water and temperature. Soybean overall development averages 135 days. The initial period (stage I) of shooting and root establishment following sowing is 20 days long. Stage II, the consolidation and vegetative development of the plant requires 30 days. The mid development period (Stage III) that 
embodies flowering requires another 60 days. The late stage (Stage IV) for maturation and ripening is about 25 days long. The crop coefficient $(\mathrm{Kc})$ values of $0.4,0.79,1.15$ and 0.5 for stages I, II , III and IV respectively indicate increasing water requirements for the crops, with a peak demand at stage III. This correlates with the yield response factor $(\mathrm{Ky})$ values of $0.4,0.8,1.0$, and 0.4 for stages 1-IV respectively, highlighting that water stress peaks at vegetative growth. This therefore implies that the risk associated with climate variability of soybeans production in general depends mainly on the growth stage of the soybeans crop. Table 3 captures the regional differences for evapotranspiration and field water supply. The reference evapotranspiration averages $29.5 \mathrm{~mm}$ in Ambam, $40.7 \mathrm{~mm}$ in Bamenda and $63.6 \mathrm{~mm}$ in Garoua, with corresponding average field water supply of 0.009 $\mathrm{l} / \mathrm{s} / \mathrm{ha}, 0.016 \mathrm{l} / \mathrm{s} / \mathrm{ha}$ and $0.41 \mathrm{l} / \mathrm{s} / \mathrm{ha}$, respectively.

Table 2: Soybean Crop Development Requirements and Indicators

\begin{tabular}{llllll}
\hline & I & II & III & IV & Total \\
\hline Stage lengths (days) & 20 & 30 & 60 & 25 & 135 \\
Kc & 0.40 & 0.79 & 1.15 & 0.50 & \\
Ky & 0.40 & 0.80 & 1.0 & 0.40 & \\
Rooting depth (m) & 0.30 & 0.50 & 1.00 & 1.00 & \\
Depletion levels (p) & 0.50 & 0.55 & 0.60 & 0.90 & \\
\hline
\end{tabular}

Notes: Ky (Yield Reduction factor), Kc (crop coefficient).

Table 3: Regional Differential for Evaportranspiration and Field Water Supply

\begin{tabular}{lccccccc}
\hline & & \multicolumn{2}{c}{ Ambam } & \multicolumn{2}{c}{ Bamenda } & \multicolumn{2}{c}{ Garoua } \\
\cline { 3 - 7 } Days & Kc & $\begin{array}{c}\text { ETo } \\
\text { (mm/period) }\end{array}$ & $\begin{array}{c}\text { FWS } \\
(\text { I/s/ha) }\end{array}$ & $\begin{array}{c}\text { ETo } \\
\text { (mm/period) }\end{array}$ & $\begin{array}{c}\text { FWS } \\
(\text { I/s/ha) }\end{array}$ & $\begin{array}{c}\text { ETo } \\
\text { (mm/period) }\end{array}$ & $\begin{array}{c}\text { FWS } \\
\text { (I/s/ha) }\end{array}$ \\
\hline 10 & 0.40 & 32.74 & 0.00 & 46.64 & 0.00 & 69.77 & 0.32 \\
20 & 0.40 & 32.63 & 0.00 & 46.24 & 0.00 & 70.03 & 0.32 \\
30 & 0.54 & 32.42 & 0.00 & 45.7 & 0.00 & 69.93 & 0.42 \\
40 & 0.79 & 32.11 & 0.00 & 45.02 & 0.00 & 69.51 & 0.55 \\
50 & 1.04 & 31.73 & 0.00 & 44.24 & 0.04 & 68.81 & 0.66 \\
60 & 1.15 & 31.28 & 0.01 & 43.4 & 0.07 & 67.91 & 0.67 \\
70 & 1.15 & 30.81 & 0.02 & 42.51 & 0.05 & 66.85 & 0.60 \\
80 & 1.15 & 30.32 & 0.02 & 41.6 & 0.04 & 65.70 & 0.55 \\
90 & 1.15 & 29.84 & 0.02 & 40.72 & 0.02 & 64.51 & 0.50 \\
100 & 1.15 & 29.39 & 0.03 & 39.88 & 0.00 & 63.34 & 0.45 \\
110 & 1.15 & 28.97 & 0.03 & 39.11 & 0.00 & 62.24 & 0.41 \\
120 & 1.01 & 28.62 & 0.00 & 38.43 & 0.00 & 61.24 & 0.27 \\
130 & 0.75 & 28.33 & 0.00 & 37.86 & 0.00 & 60.38 & 0.05 \\
140 & 0.55 & 14.08 & 0.00 & 18.76 & 0.00 & 29.92 & 0.01 \\
\hline
\end{tabular}

Estimates simulated from Cropwat 4 Windows Version 4.3.

\subsection{Crop Water Use and Irrigation Water} Requirements

The Reference Evapotranspiration (ETo) under soybean are $413.3 \mathrm{~mm}, 570.1 \mathrm{~mm}$ and $890.1 \mathrm{~mm}$ in Ambam, Bamenda and Garoua, respectively. Table 4 shows that the average crop coefficient $(\mathrm{Kc})$ for soybean is 0.68 , and the yield reduction factor (ky) is 0.85. The Evapotranspiration of the crop (ETc) is $281.03 \mathrm{~mm}$ in Ambam, $387.7 \mathrm{~mm}$ in Bamenda and $605.3 \mathrm{~mm}$ in Garoua. The estimated maximum yield for small farms in Cameroon is $2500 \mathrm{~kg}$ in Ambam, $2000 \mathrm{~kg}$ in Bamenda and $1500 \mathrm{~kg}$ in Garoua. However, the average actual yields in the farming zones are 
$1200 \mathrm{~kg}, 1500 \mathrm{~kg}$ and $800 \mathrm{~kg}$ for Ambam, Bamenda and Garoua, respectively. The computation of this information given the moisture stress factor (Ks) reveals that the actual crop evapotranspiration per growing season or the quantity of water that is actually removed from soil by soybean due to the processes of evaporation and transpiration is $25.3 \mathrm{~mm}, 15.5 \mathrm{~mm}$ and 48.4 $\mathrm{mm}$ in Ambam, Bamenda and Garoua, respectively. The average field water supply (FWS) for soybean is 0.01 litres per second per ha during the growing season in Ambam, $0.02 \mathrm{l} / \mathrm{s} / \mathrm{ha}$ in Bamenda and $0.43 \mathrm{l} / \mathrm{s} / \mathrm{ha}$ in Garoua. The finding shows that a significant proportion of pan evaporation is drawn from the soil by the mature crop. There are clear implications for coping and adapting to crop water requirements across the different agro-ecologies.
Figures 4, 5 and 6 illustrate the water requirements for soybean compared to the climatic potential in the study zones. Effective rainfall i.e. the amount of rainwater actually used by the crop increases steadily from planting time in Bamenda and Garoua farming districts, while it is almost constant in Ambam. However, between 50 and 100 days of planting, crop water requirements exceed effective rainfall in all the three zones, highlighting the need for complementary irrigation services. The irrigation water requirement per day for soybean in midcropping season in Garoua exceeds effective rain (see figure 6), revealing that the farming district suffers the effect of water deficits, and irrigation being a must. This contrasts unfavouraby with Ambam and Bamenda (see figs. 4 \& 5) with more than average effective rain at the peak of cropping season

Table 4: Crop Water Use for Soybean

\begin{tabular}{llllllllllll}
\hline $\begin{array}{l}\text { Farming } \\
\text { District }\end{array}$ & $\begin{array}{l}\text { ETo } \\
(\mathbf{m m})\end{array}$ & Kc & $\begin{array}{l}\text { ETcrop } \\
(\mathbf{m m})\end{array}$ & Ky & $\begin{array}{l}\text { Ya } \\
(\mathbf{t})\end{array}$ & $\begin{array}{l}\text { Ym } \\
(\mathbf{t})\end{array}$ & Ks & $\begin{array}{l}\text { CWR } \\
(\mathbf{m m})\end{array}$ & $\begin{array}{l}\text { ETa } \\
(\mathbf{m m})\end{array}$ & $\begin{array}{l}\text { FWS } \\
(\mathbf{l} / \mathbf{s} / \mathbf{h a})\end{array}$ & IWR \\
\hline Ambam & 413.28 & 0.68 & 281.03 & 0.85 & 1.2 & 2.5 & 0.09 & 367.23 & 25.29 & 0.01 & 11.14 \\
Bamenda & 570.11 & 0.68 & 387.67 & 0.85 & 1.5 & 2.0 & 0.04 & 504.69 & 15.51 & 0.02 & 20.31 \\
Garoua & 890.12 & 0.68 & 605.28 & 0.85 & 0.8 & 1.5 & 0.08 & 792.05 & 48.42 & 0.43 & 501.05 \\
\hline
\end{tabular}

Notes: ETo (Reference crop evapotranspiration), ETc (Evapotranspiration of the maize crop), Ky (Yield Reduction Factor), Ya (Actual Yield of Soybean Crop per farm), Ym (Maximum Yield of Soybean Crop per farm), Ks (stress factor), CWR (Crop Water Requirement), ETa (Actual Evapotranspiration), FWS (Field Water Supply), IWR (Irrigation Water Requirement).
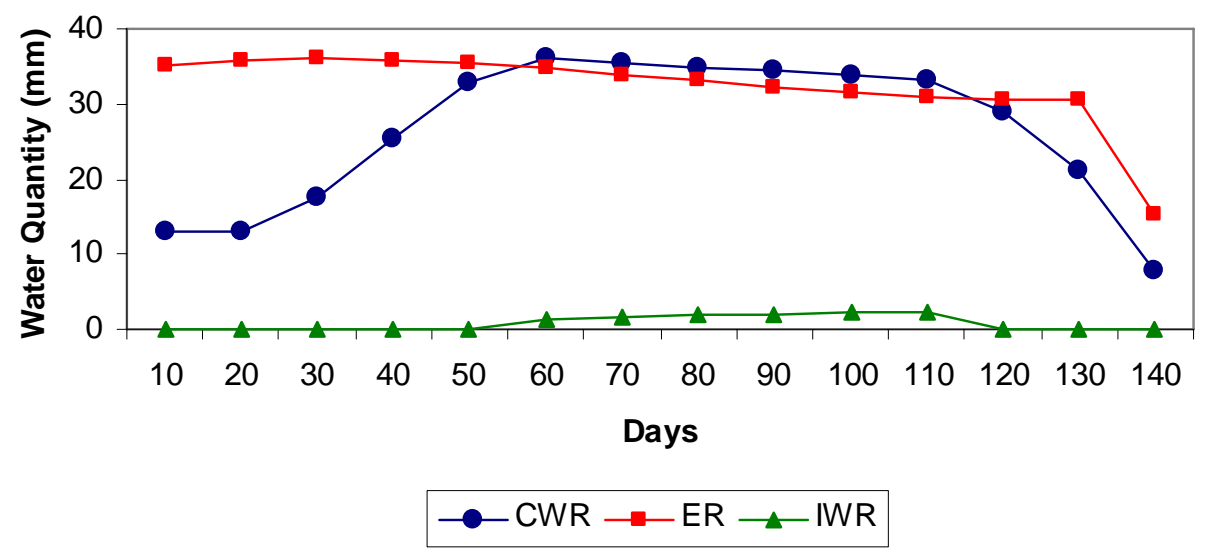

Figure 4: Water Requirement for Soybean in Ambam 


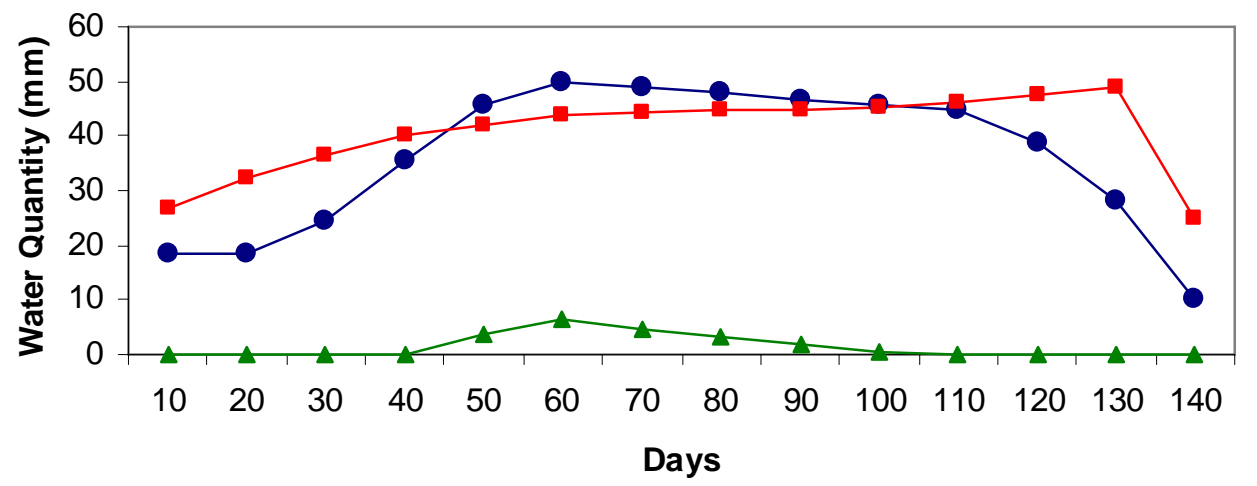

$\multimap \mathrm{CWR} \multimap-\mathrm{ER} \multimap \mathrm{IWR}$

Figure 5: Water Requirement for Soybean in Bamenda

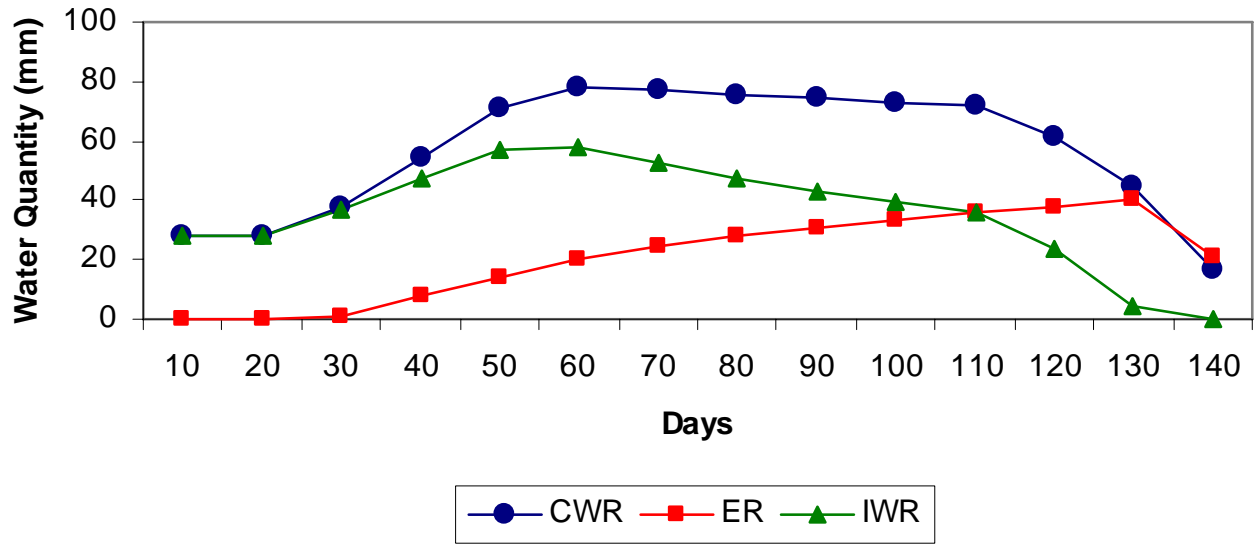

Figure 6: Water Requirement for Soybean in Garoua

\section{Discussion and Implications for Adaptation \\ to Climate Variation and Change}

Results from the present work reveal that regional climatic conditions, as wells as crop growth phases, influence crop water requirement. Both evaporation and transpiration occur in response to regional climate demand, with actual crop evapotranspiration greatest on hot dry zones as Garoua and lowest on cool humid regions of Bamenda and Ambam. While this has implications for arable crop farming in the face of climate change, complementary irrigating to provide crops with the water needed for evaporation and transpiration will reduce plant water stress at critical stages of crop development. Inasmuch as climatic aberrations are inevitable, soybeans production systems must be able to adapt to climate variations to minimize their negative effects. Observed crop management measures employed to stabilise the effects of water availability shown in figures $4,5 \& 6$ include a range of possible strategies such as: (1) adjusting the cropping calendar to synchronize crop planting and the growing period with soil moisture availability, (2) changing the soybeans variety to plant (i.e., planting a drought-tolerant or earlymaturing variety), (3) varying planting density, and (4) optimizing water-use efficiency by introducing water-saving techniques. Observations in Garoua indicate that producers' adaptation to climatic 
variation is limited to their existing resources and ability. As well as in Bamenda and Ambam, much of the methods employed are on soil and crop management. These are insufficient in the face of probabilistic climate variation. Risk coping and adaptation must be aided and abetted with governmental actions, policies and programmes. In this guise, crop improvement strategies should include the breeding of drought-tolerant varieties and lodging-resistant cultivars in national breeding programs. Drought-tolerant soybeans varieties involves the screening and testing of soybeans germplasm collections that are sources of tolerance of water stress or that require less water for crop growth. Risks associated with yield losses caused by climate variability can be partly alleviated by providing appropriate crop insurance coverage. Although crop insurance has been recognised as an effective coping strategy, it is nonexistent for subsistence agriculture and less popular among farmers because of the usually unaffordable insurance premium. Promotion of crop insurance requires not only the provision of a more reasonable insurance premium but also attractive crop insurance coverage schemes or options such as insuring not only the cost of crop establishment but also (i) the expected crop yield or (ii) the expected revenue based on harvestable crop. This must be coupled to reliable forecasts of seasonal climate. This information is important to an early warning system that supports crop production and recommends appropriate farm management measures. More important, effort must be put for seasonal climate forecasts made at a regional level, to be downscaled to specific locations to provide useful information to farmers, extension workers, traders and planners.

\section{Conclusion}

Cameroon's rain-fed agriculture has the potential to be negatively influenced by the random behavior of rainfall, causing intermittent dry spells during the cropping season and especially at critical growth stages coinciding with the terminal growth stage. The changing climatic and accompanying economic conditions lead farmers to modify their production systems. The vulnerability of soybeans to climate variability in the different agroecological zones will depend on its time of occurrence relative to the growth stage of the crop. However, advances in crop management and meteorology offer potential for knowledge-based approaches and strategies to manage, adapt and cope with climate variability and change. Supplemental irrigation is a key strategy, so far underutilised on a regional basis, to unlock rain-fed yield potentials. Supplemental irrigation to bridge dry spells in rain-fed soybeans systems has the potential of increasing yields and minimising risks for rain induced yield loss. Enhancing the choices for crop management and farm level adaptation in the advent of climatic stress will therefore require promotion of irrigation to overcome mid-cropping season dry spell and early cessation of rainfall.

\section{References}

1. IPCC, 2007. Climate Change 2007: The Physical Science Basis. Intergovernmental Panel on Climate Change, Geneva. Cambridge University Press, Cambridge, United Kingdom, 976 p.

2. Adams R. M., Hurd B. H., Lenhart S. and Leary N. 1998. Effects of global climate change on agriculture: an interpretative review. Climatic Change 11: 19-30.

3. Miller J.E., Booker F.L., Fiscus E.L., Heagle A.S., Pursley W.A., Vozzo S.F., Heck W.W. 1994. Ultraviolet-B radiation and ozone effects on growth, yield, and photosynthesis of soybean. Journal of Environmental Quality 23: 83-91.

4. Boote K.J., Jones J.W., Hoogenboom G., Wilkerson G.G. 1997. Evaluation of the CROPGROSoybean model over a wide range of experiments. In: Kropff M.J., Teng P.S., Agrawal P.K., Bouman J., Jones J.W., Van Laar H.H., (eds.) Applications of system approaches at the field level. Kluwer, Dordrecht, The Netherlands. pp. 113-133.

5. Mearns L. O., Rosenzweig C., Goldberg R. 1996. The effect of changes in daily and interannual climatic variability on CERESWheat: A sensitivity study. Climatic Change 32: 257 - 292

6. Smith M., Allen R., Monteith J.L., Pereira L.A., Perrier A., and Segeren A. 1991. Report on the Expert Consultation for the Revision of FAO Methodologies for Crop Water Requirements. FAO (AGL), Rome.

7. Izaurralde R.C., Rosenberg N.J., Brown R.A., Thomson A.M. 2003. Integrated assessment of Hadley Center (HadCM2) climate-change impacts on agricultural productivity and irrigation water supply in the conterminous United States Part II: Regional agricultural 
production in 2030 and 2095. Agric. For. Meteorol. 117: 97-122.

8. Ferris R., Wheeler T.R., Ellis R.H., Hadley P. 1999. Seed yield after environmental stress in soybean grown under elevated $\mathrm{CO}_{2}$, Crop Sci. 39: 710-718.

9. Wolf J., van Diepen C.A. 1995. Effects of climate change on grain maize yield potential in the European Community. Climatic Change 29: 299-331.

10. Maytín C.E., Acevedo M.F., Jaimez R., Andressen R., Harwell M.A., Robock A., Azkcar A., 1995. Potential effects of global climatic change on the phenology and yield of maize in Venezuela. Climatic Change 29: 189211.

11. Thompson L.M. 1986. Climatic Change, Weather Variability, and Corn Production. Agronomy Journal 78:649-653.

12. Southworth J., Randolph J.C., Habeck M., Doering O.C., Pfeifer R.A., Raoc D.G., Johnston J.J. 2000. Consequences of future climate change and changing climate variability on maize yields in the midwestern United States. Agric. Ecosystems Environ 82: 139-158.

13. Wolf J. 2002a. Comparison of two soybean simulation models under climate change. II. Application of Climate Change Scenarios. Climate Research 20:71-81.

14. Wolf J. 2002b. Comparison of two soybean simulation models under climate change. I. Model calibration and sensitivity analyses. Climate Research 20:55-70.

15. Thompson L.M. 1970. Weather and technology in the production of soybeans in the central United States. Agronomy Journal, 62: 232-236.

16. Jensen M.E., Burman R.D. and Allen R.G. 1990. Evapotranspiration and Irrigation Water Requirements. ASCE Manuals and Reports on Engineering Practice, No. 70.

17. Fiscus E.L., Reid C.D., Miller J.E., Heagle A.S. 1997. Elevated $\mathrm{CO}_{2}$ reduces $\mathrm{O}_{3}$ flux and $\mathrm{O}_{3}$ - induced yield losses in soybeans: possible implications for elevated $\mathrm{CO}_{2}$ studies. J. Exp. Botany. 48: 307-313.

18. Thompson,L.M. 1988. Effects of changes in climate and weather variability on the yield of corn and soybean. J. Prod. Agric. 1:20027.

19. Deepak S.S., Agrawal M., 2001. Influence of elevated $\mathrm{CO}_{2}$ on the sensitivity of two soybean cultivars to sulphur dioxide. Environ. Exp Botany 46: 81-91.

20. Carbone G., Kiechle W., Locke L.,Mearns L., McDaniel L., Downton M. 2003. Response of soybeans and sorghum to climate change scenarios in the southeastern United States. Climatic Change 60: 73-98.

21. Doorenbos J. and Pruitt W.O. 1975. "Guidelines for Predicting Crop Water Requirements." FAO Irrigation and Drainage Paper 24, Rome, $179 \mathrm{p}$.

22. Smith M. 1992. CROPWAT: A Computer Programme for Irrigation Planning and Management. FAO Irrigation and Drainage Paper 46, Rome, $75 \mathrm{p}$.

23. Smith M. 1993. CLIMWAT for CROPWAT: A Climatic Database for Irrigation Planning and Management. FAO Irrigation and Drainage Paper 49, Rome, $113 p$.

24. Allen R.G., Pereira L.S., Raes D. and Smith M. 1998. "Crop Evapotranspiration: Guidelines for Computing Crop Water Requirements." FAO Drainage and Irrigation Paper 56, Rome, $300 \mathrm{p}$.

25. Abraham M., Padmakumari O., and Mohan S. 2006. Evapotranspiration and Cooling System Performance for Crop Production in Greenhouses. The Journal of Agricultural Engineering Society of Sri Lanka 9(1): $33-47$

26. FAO (Food and Agriculture Organization), 2003. Water Resources, Development and Management Service. CLIMWAT: A climatic database for CROPWAT. FAO Land and Water Development Division. http://www.fao.org/ag/AGL/AGLW/climwat.stm 